\title{
ANALISIS PENGELOLAAN PARIWISATA HALAL DI DESA TETE BATU KABUPATEN LOMBOK TIMUR NUSA TENGGARA BARAT
}

\author{
Anwar $^{1}$, Arief Budi Witarto², Mega Trishuta Pathiassana ${ }^{3}$ \\ ${ }^{1 * 2}$ Pascasarjana Manajemen Inovasi Universitas Teknologi Sumbawa \\ $3^{*}$ Fakultas Teknologi Pertanian Universitas Teknologi Sumbawa \\ *Corresponding Author email: mega.trishuta@uts.ac.id, arifwitarto@gmail.com
}

\begin{abstract}
Abstrak
Diterima :

Terpilihnya NTB sebagai salah satu destinasi pariwisata halal di Indonesia

Bulan Juni 2020 menyebabkan disahkannya Perda No. 2 Tahun 2016 tentang Pariwisata Halal di NTB. Implikasi dari peraturan daerah inipun sudah banyak dilakukan. Salah satunya dengan banyak munculnya Desa wisata halal khususnya di pulau Lombok. Penelitian ini bertujuan untuk mengetahui secara detail pengelolaan pariwisata Desa wisata halal Tete Batu di Kabupaten Lombok Timur yang merupakan salah satu destinasi pariwisata halal NTB. Penelitian ini menggunakan pendekatan kualitatif dimana sampel dipilih dengan purposive sampling. Teknik pengambilan data menggunakan observasi, wawancara, dan Diterbitkan : dokumentasi. Data yang diperoleh dianalisis menggunakan tiga jalur yakni reduksi, penyajian data, dan penarikan kesimpulan yang dilakukan pada saat pengumpulan data Bulan Juli 2020 berlangsung. Keabsahan data diuji menggunakan teknik triangulasi sumber. Hasil penelitian menunjukkan bahwa pengelolaan Desa wisata halal Tete Batu meliputi beberapa aspek yaitu perencanaan, pelaksanaan, dan pengawasan. 1) Perencanaan dalam proses pengelolaan pariwisata di Desa Tete Batu seakan-akan tidak tampak, terlebih lagi untuk pengelolaan pariwisata yang notabene sudah dilaksanakan oleh masyarakat sudah sejak lama dimana konsep halal sudah sangat kental dengan kehidupan masyarakat

Keyword :

Pariwisata, Halal, Tete Batu Lombok. 2) Pelaksanaan pengelolaan terfokus pada upaya-upaya yang dilakukan pihak pengelola dalam menciptakan brand image halal yang memang sudah melekat baik dari segi fasilitas penunjang ibadah, menyediakan makanan halal, pengelolaan penginapan dengan konsep halal, dan peran serta masyarakat dalam pengelolaan sudah cukup baik walaupun masih banyak terdapat kekurangan yang harus dibenahi. 3) Pengawasan dilaksanakan dalam bentuk monitoring dan evaluasi. Fokus pengawasan terletak pada terlaksananya standarisasi pariwisata halal dan lebih jauh lagi pada evaluasi pencapaian tujuan brand image pariwisata halal adalah untuk meningkatkan jumlah kunjungan wisatawan di NTB dan lebih khusus lagi di Desa Tete Batu. Hambatan-hambatan dalam pengelolaan pariwisata hala di Desa Tete Batu antara lain kurangnya anggaran dan SDM yang menunjang pengembangan pariwisata halal.
\end{abstract}

\section{PENDAHULUAN}

Indonesia terkenal akan keindahan alamnya dan juga merupakan salah satu destinasi wisata yang sangat diminati oleh wisatawan dari dalam negeri, maupun luar negeri. Indonesia juga dikenal sebagai negara yang sangat luas, yang terdiri atas ribuan pulau besar dan kecil, Indonesia memiliki hamparan pantai yang panjang dan indah sebagai tempat wisatawan melakukan aktivitas wisata. Indonesia juga memiliki pegunungan yang keasriannya masih terjaga dan dengan kondisi iklim yang mendapat sinar matahari sepanjang tahun sehingga aktivitas kepariwisataan tidak berpengaruh oleh pergantian musim seperti negara lainnya (Maswarti, 2019).
Pariwisata saat ini merupakan salah satu penghasil devisa negara. Meningkatmya kunjungan wisatawan baik wisatawan dalam negeri dan mancanegara akan mampu mendorong berbagai mata rantai aktifias positif dalam upaya membantu meningkatkan pertumbuhan ekonomi, meningkatkan kesejahteraan rakyat, mnegurangi kemiskinan dan pengangguran (Tim Kementrian Pariwisata, 2018). Menurut Djakfar dalam Zaini (2019), bermacam-macam model pengembangan pariwisata diperkenalkan di seluruh dunia, salah satunya ialah konsep pariwisata halal. Lebih lanjut lagi dijelaskan bahwa faktorr-faktor yang mempengaruhi perkembangan dalam sektor pariwisata ini tidak hanya karena faktor iptek saja, tetapi juga dipengaruhi oleh faktor psikologis 
manusia yang cenderung menyukai sesuatu yang baru.

Indonesia merupakan negara dengan penduduk Muslim terbesar di dunia diharapkan mampu menjadi destinasi Pariwisata Syariah. Pada tanggal 17 November 2013, Presiden Susilo Bambang Yudhoyono mendeklarasikan Gerakan Ekonomi Syariah (GERS) yang diikuti oleh Program Pariwisata Syariah oleh Kementerian Pariwisata dan Ekonomi Kreatif. Kementerian Pariwisata juga menyatakan bahwa pengembangan wisata syariah harus lebih optimal. Pemerintah menetapkan tiga provinsi sebagai prioritas pengembangan, yakni Sumatera Barat, Nusa Tenggara Barat dan Nanggroe Aceh Darussalam (Tim Kementrian Pariwisata, 2018).

Konsep pariwisata halal telah menjadi tren dalam ekonomi global baik itu untuk produk makanan, minuman, keuangan, dan gaya hidup. Produk wisata halal banyak diperkenalkan di berbagai negara, bahkan di negara-negara yang mayioritas penduduknya bukan muslim seperti Jepang, Australia, Thailand, Selandia Baru, dan sebagainya. Istilah wisata halal di berbagai negara juga berbeda-beda. Mulai dari istilah Islamic Tourism, Halal Friendly Tourism Destination, Halal Travel, Muslim-Friendly Travel Destinations, dan Halal lifestyle. Bahkan di Indonesia istilah wisata halal juga belum jelas. Menurut pakar pariwisata, mengungkapkan bahwa wisata syariah merupakan produk pelengkap dari pariwisata konvensional. Pariwisata halal merupakan cara baru untuk mengembangkan pariwisata Indonesia yang menjunjung tinggi budaya dan nilai-nilai islami tanpa menghilangkan keunikan dan orisinalitas daerah (Tim Kementrian Pariwisata, 2018).

Pariwisata halal merupakan kegiatan kunjungan wisata dengan destinasi dan industri pariwisata yang menyiapkan fasilitas produk, pelayanan, dan pengelolaan pariwisata yang memenuhi syari'ah. Dalam konteks pariwisata halal, pemerintah daerah Provinsi NTB mengeluarkan Peraturan Daerah Provinsi Nusa Tenggara Barat Nomor 2 Tahun 2016 tentang Pariwisata Halal. Dalam Perda tersebut dijelaskan bahwa ruang lingkup pengaturan pariwisata halal meliputi destinasi, pemasaran dan promosi, industri, kelembagaan, pembinaan dan pengawasan dan pembiayaan. Perda tersebut mewajibkan kepada pengelola industri pariwisata konvensional untuk mengelola kegiatan pariwisatanya dengan memenuhi konsep syari'ah. Adapun industri pariwisata halal adalah usaha-usaha wisata yang menjual jasa dan produk kepariwisataan yang berpatokan pada prinsipprinsip syari'ah sebagaimana yang ditetapkan oleh Dewan Syariah Nasional Majelis Ulama Indonesia (Jaelani, 2018).
Provinsi Nusa Tenggara Barat (NTB) memiliki jumlah penduduk 4.955.678 jiwa dengan mayoritas penduduknya adalah muslim. Nusa Tenggara Barat dikenal dengan beragam kebudayaan dan tempat wisata yang sangat indah karena memiliki hamparan pantai dan pegunungan yang keasriannya masih terjaga. Dan juga terdapat beberapa kelengkapan penunjang pengembangan wisata berbasis syariah seperti hotel syariah, bank syariah, dan pegadaian syariah. Penerapkan dan pengembangkan pariwisata halal diharapkan dapat meningkatkan minat wisatawan lokal maupun asing terhadap objek wisata di NTB, agar perekonomian masyarakat dapat meningkat melalui aktivitas pariwisata ataupun wisata syariah, serta dapat mencapai target yang sudah ditentukan oleh Menteri Pariwisata yaitu 20 juta orang pada tahun 2019 (Maswarti, 2019).

Berdasarkan data kunjungan wisatawan lima tahun terakhir, perkembangan kunjungan wisatawan ke Nusa Tenggara Barat mengalami peningkatan yang signifikan dibandingkan dengan Provinsi Bali. Perkembangan kunjungan wisatawan dari tahun ke tahun, baik wisatawan mancanegara maupun wisatawan nusantara pada periode tahun 2012-2016, mengalami peningkatan rata-rata sebesar 29,84\% (Disbudpar NTB, 2019). Peningkatan data tersebut menurut Burhan Bungin disebabkan oleh brand yang dilihat wisatawan. Lebih jauh Burhan Bungin berpendapat bahwa brand akan merangsang terciptanya pembelian dan perbedaan kunjungan wisatawan di kedua provinsi disebabkan karena brand di kedua provinsi ini dikonstruksi secara berbeda sehingga memberi rangsangan yang berbeda pula kepada wisatawan yang mengunjunginya. (Bungin, 2015). Jumlah wisatawan ke Provinsi Nusa Tenggara Barat terus meningkat dari tahun ke tahunnya. Akan tetapi jumlah wisatawan yang berkunjung ke Provinsi Nusa Tenggara barat mengalami penurunan ada tahun 2018. Hal tersebut terjadi karena pada tanggal 5 Agustus 2018 Provinsi Nusa Tenggara Barat, yakni Pulau Lombok mengalami musibah yang berupa terjadinya gempa bumi (Disbudpar NTB, 2019).

Menurut Maswarti (2019), Kabupaten Lombok Timur merupakan salah satu wilayah yang berada di pulau lombok dan memiliki 20 kecamatan yang tidak kalah dengan Kabupaten lainnya yang berada di Provinsi Nusa tenggara Barat. Kabupaten Lombok Timur merupakan salah satu daerah yang memiliki begitu banyak keindahan, baik pegunungan, air terjun, pantai, danau, makam pahlawan dan masih banyak tempat wisata lainnya. Kabupaten Lombok Timur memiliki potensi untuk mengembangkan wisata maupun budaya yang ada di daerah tersebut. Daerah tersebut juga memiliki 99,92\% masyarakatnya mayoritas muslim yang 
menjadi pendukung utama dalam peroses penerapan halal tourism. Di antara tempat wisata yang berada di Kabupaten Lombok Timur adalah wisata Sembalun, Tete Batu dan Gunung Rinjani, wisata tersebut sudah masuk sebagai halal tourism di Provinsi Nusa Tenggara Barat. Beberapa tempat wisata tersebut memiliki banyak potensi, akan tetapi masih banyak kekurangan seperti perlengkapan di setiap tempat wisata yang masih kurang memadai sehingga masih perlu diperbaiki agar dapat memuaskan wisatawan yang berkunjung ke daerah tersebut dan dapat meningkatkan jumlah wisatawan setiap tahunnya. Pada penelitian ini, peneliti tertarik untuk mengkaji lebih dalam tentang pengelolaan pariwisata halal di Desa Tete Batu.

Tetebatu merupakan Desa yang berada di kawasan kaki Gunung Rinjani yang juga merupakan salah satu jalur pendakian tidak resmi menuju ke Rinjani. Bagi para wisatawan yang ingin melakukan pendakian ke Gunung Rinjani dengan pemandangan yang berbeda, dapat dilakukan dengan menggunakan jalur ini. Akan tetapi, jalur yang terdapat di Tetebatu ini tidak memungkinkan pendakian hingga ke puncak gunung. Desa Tete Batu menyuguhkan atraksi alam dan kegiatan perDesaan misalnya kegiatan sehari menjadi orang Lombok, dan atraksi wisata lainnya. Desa Tetebatu ini identik dengan daerah persawahan dan pagi yang menghampar luas sejauh mata memandang. Hal ini sesungguhnya karena wilayah ini merupakan daerah penanaman padi bagi masyarakat Lombok Timur. Penggunaan wilayah ini sebagai lahan padi dikarenakan tanahnya subur dengan air yang melimpah. Daerah wisata Tetebatu Lombok Timur ini merupakan salah satu destinasi wisata yang menarik bagi para wisatawan mancanegara. Hal ini dikarenakan aktivitas menanam padi dan kegiatan yang dilakukan di perwasahan menjadi daya tarik tersendiri bagi wisatawan asing. Lingkungan yang ada di Tetebatu masih sangat tradisional dengan nuansa perkampungan yang masih sangat kental. Kegiatan lainnya yang dapat dilakukan di Tetebatu yaitu melakukan trekking untuk mengunjungi air terjun yang terkenal di Taman Wisata Tetebatu, yaitu Air Terjun Jukut. Untuk dapat menempuh lokasi air tersebut dapat dilakukan dengan menggunakan jasa guide sebagai pendamping dengan biaya sekitar Rp 150.000,- per guide. Hal ini dilakukan untuk mendapatkan keamanan dan juga turut serta membantu perekonomian masyarakat setempat (Anonim, 2019).

Dalam penelitian ini, fokus kajian terletak pada analisis pengelolaan pariwisata halal di Desa Tete Batu sebagai implementasi dari Peraturan Daerah Provinsi Nusa Tenggara Barat Nomor 2 Tahun 2016 tentang Pariwisata Halal. Kajian serupa pernah dilakukan dalam beberapa penelitian. Penelitian Zaini (2019) tentang pengembangan pariwisata halal berbasis masyarakat di Desa Sembalun yang fokus penelitiannya terletak pada strategi pengembangan pariwisata dan dampaknya bagi masyarakat. Penelitian Ahyak (2018) tentang strategi pengelolaan pariwisata halal di kota Surabaya yang fokus kajiaanya terletak pada strategi pengelolaan, hambatan, dan daya dukung pariwisata halal di Makam Sunan Ampel.

Berdasarkan uraian di atas, peneliti tertarik untuk mengkaji lebih dalam tentang pengelolaan pariwisata halal di Desa Tete Batu sebagai implikasi dari Peraturan Daerah Provinsi Nusa Tenggara Barat Nomor 2 Tahun 2016 tentang Pariwisata Halal baik dari segi manajemen, daya dukung, dan hambatan.

\section{LANDASAN TEORI}

Analisis Pengelolaan

Menurut Komaruddin (2001), analisis merupakan kegiatan berpikir untuk menguraikan suatu keseluruhan menjadi komponen sehinga dapat mengenal tanda-tanda komponen, hubungannya satu sama lain dan fungsi masingmasing dalam satu keseluruhan yang terpadu. Hal senada juga disampaikan oleh Harahap (2004) yang menyatakan bahwa analisis merupakan suatu upaya untuk memecahkan atau menguraikan sesuatu unit menjadi berbagai unit terkecil. Berdasarkan uraian tersebut dapat disimpulkan bahwa analisis merupakan kegiatan berpikir untuk menguraikan suatu pokok menjadi bagian atau komponen sehingga dapat diketahui ciri atau tanda di setiap tiap bagian atau komponen, hubungannya satu sama lain hingga fungsi masing-masingnya.

Pengelolaan berasal dari kata kelola, dalam Kamus Besar Bahasa Indonesia Kontemporer karangan Peter Salim dan Yenny Salim (2002), berarti memimpin, mengendalikan, mengatur, dan mengusahakan supaya lebih baik, lebih maju dan sebagianya serta bertanggung jawab atas pekerjaan tertentu. Pengelolaan adalah proses yang membantu merumuskan kebijaksanaan dan tujuan memberikan pengawasan pada semua hal yang terlibat dalam pelaksanaan dan pencapaian tujuan. Menurut Handayaningrat (2003) pengelolaan juga bisa diartikan penyelenggaraan suatu kegiatan. Pengelolaan bisa diartikan manajemen, yaitu suatu proses kegiatan yang di mulai dari perencanaan, pengorganisasian, pengarahan dan pengawasan usaha-usaha para anggota organisasi dan penggunaan-penggunaan sumber daya sumber daya organisasi lainnya agar mencapai tujuan organisasi yang telah ditentukan. Tujuan pengelolaan adalah agar segenap sumber daya yang ada seperti, sumber daya manusia, peralatan atau sarana yang ada 
dalam suatu organisasi dapat digerakan sedemikian rupa, sehingga dapat menghindarkan dari segenap pemborosan waktu, tenaga dan materi guna mencapai tujuan yang diinginkan. Pengelolaan dibutuhkan dalam semua organisasi, karena tanpa adanya pengelolan atau manajemen semua usaha akan sia-sia dan pencapaian tujuan akan lebih sulit.

Menurut Henry Fayol dalam Handoko (2012) fungsi pengelolaan adalah suatu proses pengarahan dan pemberian fasilitas kerja kepada orang yang diorganisasikan dalam kelompok formal untuk mencapai tujuan. Lebh lanjut lagi dikemukakan ada 5 fungsi pengelolaan yaitu Planning (Perencanaan), Organizing (Pengorganisasian), Commanding (Pemberian perintah), Coordinating (Pengkoordinasian), dan Controlling (Pengawasan). Pengelolaan yang baik merupakan elemen penting untuk memastikan organisasi bekerja sesuai dengan kepentingan anggotanya.

Menurut Terry (2006) menjelaskan bahwa pengelolaan yang baik meliputi :

1. Perencanaan (Planning) adalah pemilihan faktafakta dan usaha menghubungkan fakta satu dengan lainnya, kemudian membuat perkiraan dan peramalan tentang keadaan dan perumusan tindakan untuk masa yang akan datang yang sekiranya diperlukan untuk mencapai hasil yang dikehendaki.

2. Pengorganisasian (Organizing) diartikan sebagai kegiatan mengaplikasikan seluruh kegiatan yang harus dilaksanakan antara kelompok kerja dan menetapkan wewenang tertentu serta tanggung jawab sehingga terwujud kesatuan usaha dalam pencapaian tujuan yang telah ditetapkan.

3. Penggerakan (Actuating) adalah menempatkan semua anggota daripada kelompok agar bekerja secara sadar untuk mencapai suatu tujuan yang telah ditetapkan sesuai dengan perencanaan dan pola organisasi.

4. Pengawasan (Controlling) diartikan sebagai proses penentuan yang dicapai, pengukuran dan koreksi terhadap aktivitas pelaksanaan dan bilamana perlu mengambil tindakan korektif terhadap aktivitas pelaksanaan dapat berjalan menurut rencana.

Berdasarkan uraian di atas, konsep pengelolaan dapat disederhanakan menjadi perencanaan, pelaksanaan, dan pengawasan

\section{Pariwisata Halal Di Nusa Tenggara Barat}

Wisata halal atau yang dahulu sering disebut sebagai pariwisata berbasis syariah telah diperkenalkan sejak tahun 2000 dari pembahasan pertemuan OKI. Pariwisata syariah merupakan suatu permintaan wisata yang didasarkan pada gaya hidup wisatawan muslim selama liburan. Selain itu, pariwisata syariah merupakan pariwisata yang fleksibel, rasional, sederhana dan seimbang. Pariwisata ini bertujuan agar wisatawan termotivasi untuk mendapatkan kebahagiaan dan berkat dari Allah (Tim Kementrian Pariwisata, 2018) . Karakteristik pariwisata syariah meliputi:

1. Pelayanan kepada wisatawan harus cocok dengan prinsip muslim secara keseluruhan,

2. Pemandu dan staf harus memiliki disiplin dan menghormati prinsip-prinsip Islam,

3. Mengatur semua kegiatan agar tidak bertentangan dengan prinsip Islam,

4. Bangunan harus sesuai dengan prinsip-prinsip Islam,

5. Restoran harus mengikuti standar internasional pelayanan halal,

6. Layanan transportasi harus memiliki keamanan sistem proteksi,

7. Ada tempat-tempat yang disediakan untuk semua wisatawan muslim melakukan kegiatan keagamaan, dan

8. Bepergian ke tempat-tempat yang tidak bertentangan dengan prinsip Islam

Provinsi NTB merupakan salah satu dari beberapa destinasi prioritas untuk wisata halal di Indonesia, yang mana industri pariwisata Provinsi NTB terus mengalami kemajuan yang cukup baik. Hal tersebut tidak terlepas dari adanya keterbukaan masyarakat wilayah Provinsi NTB. Dalam konteks pariwisata halal sendiri, pariwisata NTB telah memiliki beberapa prestasi. Provinsi NTB mendapatkan 3 (tiga) penghargaan di ajang The World Halal Tourism Awards 2016. Pemerintah kemudian menunjuk NTB sebagai salah satu destinasi wisata halal nasional dan sebagai salah satu dari 10 (sepuluh) destinasi prioritas yang memiliki visi “World's Best Halal Tourism and Cruise Destination". Pemerintah Daerah mengambil langkah dengan mengesahkan Peraturan Daerah No. 2 Tahun 2016 tentang Pariwisata Halal. Dalam Peraturan Daerah No. 2 Tahun 2016, ruang lingkup pengaturan Pariwisata Halal meliputi destinasi, pemasaran dan promosi, industri, kelembagaan, pembinaan dan pengawasan, dan pembiayaan.

Di NTB banyak terdapat destinasi wisata, salah satunya adalah Desa wisata Tete Batu. Menurut Khafid (2019) dalam Lombok News menjelaskan bahwa Tete Batu adalah Desa wisata sejak zaman Belanda dahulu kala. Lokasinya di bawah gunung Rinjani. Desa Wisata Tete Batu ini menjadi salah satu tempat untuk menikmati pesona keindahan pemandangan di kaki selatan gunung Rinjani, yang memiliki pesona keindahan panorama pegunungan dan persawahan, kontur tanah di Tete Batu seperti anak tangga yang membentuk persawahan subur nan hijau. Dilokasi ini juga sering menjadi buruan 
para pecinta fotografer khususnya mereka yang ingin mengambil keindahan sunsrise yang sangat menawan, dan di kala senja datang, wisatawan akan merasakan seolah-olah menyatu dengan keadaan alam yang begitu tenang, sunyi, dan sejuk. Di tambah dengan pemandangan langit yang bewarna merah keemasan, berpadu dengan kokohnya puncak Gunung Rinjani. Di Desa Tete Batu menyuguhkan berbagai macam atraksi wisata. Namun yang lebih dominan dan terkenal di kalangan wisatawan adalah keindahan atraksi wisata alamnya. Atraksi wisata alam yang disuguhkan berkaitan dengan atraksi wisata alam di Desa Tete Batu dan Desa Tete Batu Selatan. Adapun atraksi wisata alam yang disuguhkan Desa Tete Batu antara lain Lembah Ulem-ulem, kebun holtikultura, kawasan hutan kera, perkebunan tembakau, dan air terjun.

\section{METODE PENELITIAN}

Dalam penelitian ini penulis menggunakan jenis penelitian kualitatif. Penelitian kualitatif adalah suatu penelitian yang perlu dilakukan yang sesuai dengan masalah yang diteliti (Maleong, 2007). Ada juga yang mengartikan suatu prosedur yang menggunakan data deskriptif berupa kata-kata tertulis atau lisan dari orang-orang dan pelaku yang bisa diamati. Penelitian kualitatif cenderung berkembang dan banyak digunakan dalam ilmuilmu sosial yang berhubungan dengan perilaku sosial/manusia, dengan berbagai argumentasi tentunya (Sudrajat, 2005).

Waktu pelaksanaan penelitian dari bulan Agustus 2019 sampai dengan Januari 2020 bertempat di Desa Tete Batu Kabupaten Lombok Timur NTB. Pemilihan sumber data dalam penelitian ini dengan cara purposive sampling yaitu sumber data dengan pertimbangan tertentu (Sugiyono, 2013).Untuk mendapatkan data yang komprehensif, maka informan tidak hanya berasal dari kalangan dinas, tetapi juga melibatkan pemerintah Desa, pokdarwis, tokoh masyarakat dan masyarakat pelaku wisata.

Teknik pengumpulan data yang digunakan dalam penelitian ini adalah observasi, wawancara dan dokumentasi. Dalam penelitian ini digunakan metode interview bebas terpimpin yang merupakan kombinasi interview bebas dengan interview terpimpin, dimana pewawancara membawa pedoman yang hanya merupakan garis besar tentang hal-hal yang ditanyakan. Sebagai instrumen adalah interview guidance atau pedoman wawancara. Dokumentasi merupakan catatan peristiwa yang sudah berlalu. Dokumen bisa berbentuk tulisan, gambar, atau karya-karya monumental. Dalam penelitian ini diperoleh dokumen dalam bentuk tulisan berapa peraturan dan kebijakan terkait pariwisata halal.
Dalam penelitian ini digunakan teknik triangulasi sumber untuk mengecek keabsahan data yang diperoleh. Hal ini ditunjukkan dengan jumlah responden wawancara lebih dari satu responden. Selain teknik triangulasi, keabsahan data dalam penelitian juga dicek dengan mendiskusikan dan menyeminarkan dengan pakar atau orang yang lebih ahli termasuk koreksi di bawah bimbingan dosen pembimbing. Dimana dengan hal itu dapat membicarakan dan menanyakan berbagai hal termasuk metode yang digunakan, kesimpulankesimpulan sementara yang diperoleh peneliti serta adanya bias yang disebabkan oleh peneliti. Sehingga kita bisa mendapat kritik dan memberi masukan segala macam proses penelitian. Sehingga terjadi interaksi yang dapat mendukung pelaksanaan penelitian dengan baik.

Menurut Miles dan Huberman dalam Sugiyono (2013), bahwa analisis data penelitian kualitatif dapat dilakukan melalui tiga jalur kegiatan yang terjadi secara bersamaan yaitu: (1) reduksi data (data reduction), (2) penyajian data (data displays), dan (3) penarikan kesimpulan/verifikasi ( conclusion drawing / veriffication). Analisis data dalam penelitian kualitatif, dilakukan pada saat pengumpulan data berlangsung dan setelah selesai pengumpulan data. Pada saat wawancara, peneliti sudah melakukan analisis terhadap jawaban yang diwawancarai. Bila jawaban yang diwawancarai setelah dianalisis belum memuaskan, maka peneliti melanjutkan pertanyaan lagi sampai tahap tertentu sampai diperoleh data yang dianggap kredibel.

\section{HASIL DAN PEMBAHASAN}

\section{Analisis Pengelolaan Pariwisata Hala di Desa Tete Batu Kabupaten Lombok Timur NTB}

Di Desa Tete Batu menyuguhkan berbagai macam atraksi wisata. Namun yang lebih dominan dan terkenal di kalangan wisatawan adalah keindahan atraksi wisata alamnya. Atraksi wisata alam yang disuguhkan berkaitan dengan atraksi wisata alam di Desa Tetebatu dan Desa Tete Batu Selatan.

Pengelolaan pariwisata halal di Desa Tete Batu terbagi menjadi 3 aspek yaitu perencanaan, pelaksanaan, dan pengawasan. Proses perencanaan pada pengelolaan konsep pariwisata halal di Desa Tete Batu tidak mengalami banyak hambatan. Hal ini disebabkan secara keseluruhan penduduk Desa Tete Batu beragama Islam sehingga standarisasi pariwisata halal sudah banyak dilakukan. Selain karena penduduk yang seluruhnya muslim, faktor penting dalam kemudahan dalam proses perencanaan adalah karena pengelolaan wisata di Desa Tete Batu sudah ada bahkan dari zaman Belanda. Dokumentasi dari Khafid (2019) dalam Lombok News menjelaskan bahwa Tete Batu 
adalah Desa wisata sejak zaman Belanda dahulu kala. Sejak zaman Belanda Desa Tete Batu ini dikenal sebagai tempat beristirahat yang sejuk dan tenang. Seorang dokter pertama ahli malaria, lepra, kusta yang bertugas di Kabupaten Lombok Timur, almarhum dr.Raden Soedjono, sekitar 1925 - 1930 menjadikannya sebagai tempat beristirahat di akhir pekan karena ketenangan dan kesejukan di Desa Tete Batu. Setelah meninggal, 1944, Wisma Sudjono ditempati dan dikelola oleh kerabat dan keturunannya. Wisma inilah yang menjadi cikalbakal pariwisata di Desa Tete Batu. Pengalaman pengelolaan yang sudah cukup lama dimana standar pengelolaannya sudah disesuaikan dengan agama dan kebiasaan masyarakat di Desa Tete Batu.

Perencanaan dalam proses pengelolaan pariwisata di Desa Tete Batu seakan-akan tidak tampak, terlebih lagi untuk pengelolaan pariwisata halal yang notabene sudah dilaksanakan oleh masyarakat sudah sejak lama. Apalagi lombok terkenal dengan sebutan "Pulau Seribu Masjid" yang mengindikasikan konsep halal sudah sangat kental dengan kehidupan masyarakat Lombok. Hal inilah yang menyebabkan kemudahan dalam perencanaan dan hampir tidak tampak dalam proses pengelolaan pariwisata halal di Desa Tete Batu. Berdasarkan hasil wawancara juga dapat dijelaskan bahwa tidak ada perencanaan khusus terkait pariwisata halal, baik oleh dinas terkait maupun lembaga non-pemerintah lainnya.

Tahap perencanaan pada pengelolaan pariwisata halal di Desa Tete Batu tidak begitu tampak karena standarisasi wisata halal sebagian besar sudah melekat pada kehidupan masyarakat Desa Tete Batu. Perencanaan lain yang dilakukan adalah perencanaan yang menunjang keberlangsungan proses pariwisata di Desa Tete Batu. Perencanaan tersebut antara lain perencanaan dalam membuat spot-spot baru, promosi, dan akomodasi.

Dalam proses pelaksanaan, strategi mendasar dalam pengelolaan pariwisata di Desa Tete Batu adalah adanya kerjasama dengan lembaga pemerintah dan non pemerintah. Lembaga pemerintah seperti Dinas Pariwisata telah banyak melakukan intervensi terkait pengelolaan pariwisata halal di Desa Tete Batu terutama menyangkut akses dan standarisasi SDM. Ada beberapa item, yakni intervensi di bidang SDM, penyiapan SDM, sertifikasi tenaga kerja atau guide 40 orang. Dari segi infrastruktur, dinas juga telah mengintervensi beberapa produk seperti pembangunan jalan untuk akses beberapa jalan. Pemerintah sudah mulai bergegas memperbaiki segala sesuatu terkait wisata halal. Market atau promosi, dinas pariwisata ada 3 bidang, yaitu pengembangan destinasi, kapasitas, dan pemasaran atau promosi. 3 bidang membangun 1 sistem untuk mem-blow up satu produk wisata.

Selain dinas terkait, pemerintah Desa juga memberikan kerjasama yang sudah cukup baik. Untuk mengembangkan pariwisata halal, pemerintah Desa mendukung kegiatan-kegiatan yang dilaksanakan oleh pemerintah provinsi dan daerah. Sebagai wujud peran pemerintah Desa adalah dengan membentuk kelompok-kelompok dari Desa yang akan dikelola oleh masyarakat. Memberikan kemudahan masyarakat untuk meminta bantuan dana. Misalnya, masyarakat ingin membuat fasilitas wisata dapat mengajukan proposal dan diberikan kemudahan. Adanya realisasi bantuan kementerian 1 unit bungalow dan realisasi pelatihan jdari kementerian tentang pariwisata halal.

Dari segi konsep halal, pengelolaan pariwisata Desa Tete Batu sudah banyak yang sesuai standarisasi konsep pariwisata halal sesuai Perda No. 2 tahun 2016. Terdapatnya fasilitas umum yang memudahkan untuk tempat beribadah bagi yang muslim. Tempat ibadah seperti masjid sudah terdapat di kawasan Desa Tete Batu. Masjid memiliki tempat untuk bersuci. Untuk home stay yang dikelola langsung oleh masyarakat juga sudah mulai mengarah ke standarisasi pariwasata halal, bahkan tamu yang datang berpasangan harus menunjukkan buku nikah sebelum memasuki kawasan atau menginap. Berdasarkan hasil wawancara dapat dikatakan bahwa pelayanan makanan dan minuman $100 \%$ halal. Hal ini karena pengolahan makanan dan minuman langsung dilakukan oleh masyarakat Desa Tete Batu yang notabene seluruhnya beragama islam. Hal ini dapat mengindikasikan halalnya pelayanan makanan dan minuman di Desa Tete Batu. Konsep halal sudah melekat pada kehidupan masyarakat Desa Tete Batu sehingga pariwisatanya pun sekiranya dapat dikategorikan pariwisata halal. Namun sekiranya perlu juga sertifikasi-sertifikasi halal dari Dewan Syari'ah Nasioan Majellis Ulama Indomensia (DSN-MUI) guna mempertegas kehalalan pelayanan pariwisata di Desa Tete Batu.

Selain tersedianya tempat ibadah bagi yang muslim dan makanan yang halal, pengelolaan destinasi pariwisata halal juga menyangkut peningkatan kapasitas dan peran serta masyarakat dalam proses pengelolaan usaha wisata halal. Peran serta masyarakat dalam pengelolaan pariwisata halal Desa Tete Batu sangat jelas terlihat. Sistem pengelolaan pariwisata di Desa Tete Batu adalah sistem pengelolaan yang dikelola oleh masyarakat setempat. Dimana rumah masyarakat sendiri dijadikan sebagai homestay. Penginapan dikelola oleh masyarakat setempat meskipun dengan lahan yang sempit namun dengan konsep homestay ini jika ada tamu yang menginap, maka yang 
disediakan oleh masyarakat bukan hanya tempat tidur tapi juga makanan dan lain-lain dalam bentuk paket penginapan. Biasanya banyak turis yang tinggal atau menginap lama karena mereka biasanya tertarik untuk mengetahui pola kebiasaan yang ada di masyarakat yang tidak mereka temui di negeranya seperti keramahtamahan masyarakat, gotong royong, kearifan lokal yang ada. Selain itu, promosi tete batu melalui buku atau media sosial tidaklah berbeda dengan kenyataannya, dan inilah salah satu alasan juga kenapa tamu atau turis tetap datang ke Tete Batu.

Masyarakat juga dilibatkan langsung dalam atrakasi wisata budatya misalnya kegiatan budaya dimana mengumpulkan semua kalangan masyarakat agar masyarakat dapat membuat pentas yang akan ditampilkan. Dimana dalam pentas masyarakat bergabung dalam suatu komunitas yang dinamakan komunitas entries Tete Batu.

Peran serta masyarakat dalam pariwisata halal juga telah diatur dalam Perda No. 2 Tahun 2016. Dalam Perda disebutkan bahwa pemberdayaan masyarakat melalui pariwisata halal meliputi penguatan kesadaran masyarakat, peningkatan kapasitas dan peran masyarakat dalam pengelolaan usaha, dan peningkatan pendapatan masyarakat. Penguatan kesadaran masyarakat dilakukan dalam bentuk sosialisasi tentang penyelenggaraan pariwisata halal. Peningkatan kapasitas dan peran masyarakat meliputi, meningkatkan pemahaman, dukungan dan partisipasi masyarakat dalam mewujudkan pengelolaan pariwisata halal, meningkatkan motivasi dan kemampuan masyarakat dalam pengelolaan pariwisata halal, dan melibatkan masyarakat dalam perumusan kebijakan-kebijakan yang terkait dengan kepariwisataan halal. Peningkatan pendapatan masyarakat melalui usaha pariwisata halal meliputi menciptakan kesempatan berusaha dalam aktivitas kepariwisataan halal memberikan insentif.

Peningkatan pendapatan masyarakat melaui usaha pariwisata halal sudah lama dilakukan dalam pengelolaan wisata halal di Desa Tete Batu sehingga dikatakan pengelolaan berbasis masyarakat. Hasli penelitian Zaini (2019) menunjukkan bahwa masyarakat tidak lagi menjadi objek tetapi menjadi subjek yang terlibat aktif mulai dari perencanaan, pelaksanaan, dan monitoring bahkan juga sebagai produsen dalam proses pariwisata. Dengan model ini, memungkinkan untuk meningkatan kesejahteraan masyarakat.

Pelaksanaan pengelolaan terfokus pada upayaupaya atau hal-hal yang dilakukan pihak pengelola dalam menciptakan brand image halal yang memang sudah melekat baik dari segi fasilitas umum penunjang ibadah, menyediakan makanan halal, pengelolaan penginapan dengan konsep halal, dan peran serta masyarakat dalam pengelolaan. Walaupun belum diperoleh data terkait standarisasi berupa sertifikat halal dari DSN-MUI, namun berdasarkan hasil wawancara dan temuan di lapangan dapat disimpulkan bahwa pengelolaan pariwisata hala di Desa Tete Batu sudah cukup baik walaupun masih banyak terdapat kekurangan yang harus dibenahi.

Pengawasan dalam pengelolaan pariwisata halal Desa Tete Batu dirasa masih kurang maksimal karena tidak ada data yang menunjukkan adanya pengawasan oleh Dinas dan dapat melibatkan DSN-MUI (Dewan Syari'ah Nasional Majelis Ulama Indonesia), PHRI (Perhimpunan Hotel dan Restoran Indonesia), ASITA (Association of The Indonesian Tours and Travel Agencies), HPI (Himpunan Pramuwisata Indonesia), FKD (Forum Kepariwisataan Daerah), dan BPPD (Badan Promosi Pariwisata Daerah). Pengawasan dilaksanakan dalam bentuk monitoring dan evaluasi sesuai dengan Perda No. 2 Tahun 2016. Dari konteks pengawasan, fokusnya terletak pada pelaksanaan standarisasi pariwisata halal dan lebih jauh lagi pada evaluasi pencapaian tujuan brand pariwisata halal adalah untuk meningkatkan jumlah kunjungan wisatawan di NTB dan lebih khusus lagi di Desa Tete Batu. Dengan adanya pariwisata halal kunjungan wisatawan meningkat. Pariwisata Tete Batu masuk dalam domain wisata Sembalun yang pernah mendapat penghargaan The Best Pariwisata. Zonasi banyak untuk kawasan kuliner, pantai, air terjun, agrowisata. Secara tidak langsung pelaku pariwisata sudah membangun jaringan sendiri (zonasi) yang saling mendukung. Adanya jaringan dan brand halal ini yang mendukung peningkatan jumlah kunjungan wisatawan.

Peningkatan wisatawan tejadi, namun masih terfokus pada wisatawan yang berasal dari Amerika, Eropa, dan Autralia, Belum banyak menyentuh wisatawan Asia terlebih lagi wisatawan timur tengah. Hal ini sekiranya disebabkan oleh kebutuhan wisata dari wisatawan timur tengah yang lebih banyak ke wisata religi, pantai, hotel berbintang, dan restoran mewah. Hal ini merupakan tantangan bagi pihak pengelola baik lembaga pemerintah maupun non-pemerintah untuk lebih mengembangkan destinasi pariwisata halal secara umum untuk dapat menarik pasar wisatawan di seluruh benua.

\section{Analisis Hambatan Dalam Pengelolaan Pariwisata Hala di Desa Tete Batu Kabupaten Lombok Timur NTB}

Pariwisata Desa Tete Batu pernah jaya pada masanya. Seiring berjalannya waktu banyak fasilitas pariwisata yang rusak menyebabkan pariwisata Desa Tete Batu mengalami kemunduran. Ditambah lagi dengan adanya destinasi-destinasi 
wisata lainnya di pulau Lombok. Brand Image pariwisata halal yang disematkan kepada provinsi NTB ditindaklajuti dengan terbitnya Pergub No.51 Tahun 2015 dan Perda No. 2 Tahun 2016. Brand Image halal diharapkan dapat mengdongkrak kembali pariwisata di NTB terlebih lagi untuk pariwisata di Desa Tete Batu yang pernah jaya pada masanya. Pengelolaan pariwisata halal trus digaungkan pemerintah. Tidak terlepas juga di Desa Tete Batu yang diharapkan dapat mengangkat kembali kegiatan pariwisatanya.

Dalam proses pengelolaan pariwisata halal di Desa Tete Batu tentunya terdapat hambatan. Hambatan utama yang dirasakan dalam pengelolaan adalah anggaran. Karena membangun suatu tempat wisata itu butuh anggaran yang besar. Bukan hanya membangun spot wisata kemudian selesai. Anggaran perkembangan kapasitas. Anggaran dapat digunakan untuk membangun spot wisata baru untuk menanmbah daya tarik wisatawan ke Desa Tete Batu. Anggaran juga dapat digunakan untuk sarana prasarana penting lainnya yang dapat mendukung proses pengelolaan pariwisata. Misalnya sarana jalan menuju ke destinasi wisata yang memadai. Di Desa Tete Batu, atraksi wisata alamnya lebih dominan dapat dikunjungi dengan menyusuri persawahan dan hutan. Tentu saja dengan adanya akses jalan yang baik akan dapat meningkatkan minat kunjungan ke Desa Tete Batu. Walaupun dengan menyusuri persawahan dan hutan para wisatawan juga dapat menikmati keindahan panorama Desa Tete Batu. Jika akses jalan memadai, maka sarana pendukung pariwisata halal seperti tempat ibadah dapat dibangun lebih banyak di pinggir jalan untuk meningkatkan image halal di Desa Tete Batu.

Menurut Perda No. 2 tahun 2016 tentang pariwisata halal, pembiayaan atas pengelolaan pariwisata halal oleh Pemerintah Daerah bersumber dari dianggarkan pada Anggaran Pendapatan dan Belanja Daerah dan/atau sumber lain yang sah dan tidak mengikat. Sumber lain yang tidak mengikat bisa dari sumbangan atau swadaya masyarakat. Namun tentunya untuk pembiayaan yang besar swadaya masyarakat tidak akan mencukupi, terlebih lagi masyarakat Desa Tete Batu sebagian besar memiliki mata pencaharian sebagai petani. Sehingga pembiayaan utama masih tergantung pada pemerintah daerah.

Selain hambatan dari segi anggaran, hambatan lainnya yang dirasakan adalah kurangnya SDM yang memadai. Peningkatan SDM dalam pengelolaan pariwisata terutama untuk brand pariwisata halal tidak hanya terfokus pada bahasa, tetapi juga pada standarisasi pengelolaan pariwisata halal. Peningkatan SDM dapat dilakukan melalui pembinaan oleh Dinas Pariwisata. Pembinaan harus melibatkan DSN-MUI (Dewan Syari'ah Nasional
Majelis Ulama Indonesia). Selain itu pembinaan dapat melibatkan BPPD (Badan Promosi Pariwisata Daerah), PHRI (Perhimpunan Hotel dan Restoran Indonesia), ASITA (Association of The Indonesian Tours and Travel Agencies), FKD (Forum Kepariwisataan Daerah), dan HPI (Himpunan Pramuwisata Indonesia). Pembinaan dilakukan dalam bentuk sosialisasi, stimulasi dan bimbingan dan pelatihan.

\section{PENUTUP}

Kesimpulan

Berdasarkan hasil penelitian dan pembahasan dapat diambil kesimpulan sebagai berikut :

1. Pengelolaan pariwisata halal di Desa Tete Batu terbagi menjadi 3 aspek yaitu perencanaan, pelaksanaan, dan pengawasan. 1) Perencanaan dalam proses pengelolaan pariwisata di Desa Tete Batu seakan-akan tidak tampak, terlebih lagi untuk pengelolaan pariwisata halal yang notabene sudah dilaksanakan oleh masyarakat sudah sejak lama. Apalagi lombok terkenal dengan sebutan "Pulau Seribu Masjid" yang mengindikasikan konsep halal sudah sangat kental dengan kehidupan masyarakat Lombok. 2) Pelaksanaan pengelolaan terfokus pada upaya-upaya atau hal-hal yang dilakukan pihak pengelola dalam menciptakan brand image halal yang memang sudah melekat baik dari segi fasilitas umum penunjang ibadah, menyediakan makanan halal, pengelolaan penginapan dengan konsep halal, dan peran serta masyarakat dalam pengelolaan. Walaupun belum diperoleh data terkait standarisasi berupa sertifikat halal dari DSN-MUI, namun berdasarkan hasil wawancara dan temuan di lapangan dapat disimpulkan bahwa pengelolaan pariwisata hala di Desa Tete Batu sudah cukup baik walaupun masih banyak terdapat kekurangan yang harus dibenahi. 3) Pengawasan dalam pengelolaan pariwisata halal Desa Tete Batu dirasa masih kurang maksimal karena tidak ada data yang menunjukkan adanya pengawasan oleh Dinas dan dapat melibatkan DSN-MUI, PHRI, ASITA, HPI FKD, dan BPPD. Pengawasan dilaksanakan dalam bentuk monitoring dan evaluasi sesuai dengan Perda No. 2 Tahun 2016. Dari konteks pengawasan, fokusnya terletak pada pelaksanaan standarisasi pariwisata halal dan lebih jauh lagi pada evaluasi pencapaian tujuan brand pariwisata halal adalah untuk meningkatkan jumlah kunjungan wisatawan di NTB dan lebih khusus lagi di Desa Tete Batu.

2. Hambatan-hambatan dalam pengelolaan pariwisata hala di Desa Tete batu

a. Hambatan utama yang dirasakan dalam pengelolaan adalah anggaran. Menurut 
Perda No. 2 tahun 2016 tentang pariwisata halal, pembiayaan atas pengelolaan pariwisata halal oleh Pemerintah Daerah bersumber dari dianggarkan pada Anggaran Pendapatan dan Belanja Daerah dan/atau sumber lain yang sah dan tidak mengikat. Sumber lain yang tidak mengikat bisa dari sumbangan atau swadaya masyarakat. Namun tentunya untuk pembiayaan yang besar swadaya masyarakat tidak akan mencukupi, terlebih lagi masyarakat Desa Tete Batu sebagian besar memiliki mata pencaharian sebagai petani. Sehingga pembiayaan utama masih tergantung pada pemerintah daerah.

b. Kurangnya SDM yang memadai. Peningkatan SDM dalam pengelolaan pariwisata terutama untuk brand pariwisata halal tidak hanya terfokus pada bahasa, tetapi juga pada standarisasi pengelolaan pariwisata halal. Peningkatan SDM dapat dilakukan melalui pembinaan oleh Dinas Pariwisata. Pembinaan harus melibatkan DSN-MUI (Dewan Syari'ah Nasional Majelis Ulama Indonesia). Selain itu pembinaan dapat melibatkan BPPD (Badan Promosi Pariwisata Daerah), PHRI (Perhimpunan Hotel dan Restoran Indonesia), ASITA (Association of The Indonesian Tours and Travel Agencies), FKD (Forum Kepariwisataan Daerah), dan HPI (Himpunan Pramuwisata Indonesia). Pembinaan dilakukan dalam bentuk sosialisasi, stimulasi dan bimbingan dan pelatihan.

\section{REFERENSI}

Buku, Laporan, Jurnal, dan Tesis

Ahyak. 2018. Strategi Pengelolaan

Pariwisata Halal Di Kota Surabaya (Studi

Kasus Pada Wisata Makam Sunan

Ampel). Tesis UIN Sunan Ampel

Surabaya

Bappenas. 2013. Koridor Ekonomi Bali-Nusa Tenggara Barat. Jakarta. Bappenas.

Bungin, Burhan 2015. Komunikasi

Pariwisata: Pemasaran dan Brand

Destinasi. Kencana. Jakarta.

Djakfar, Muhammad. 2017. Pariwisata Halal Perspektif Multidimensi, Peta Jalan

Menuju Pengembangan Akademik \&

Wisata Halal Indonesia. Malang : UIN

Maliki Press

Dinas Kebudayaan dan Pariwisata Provinsi

Bali. (2017). Laporan Kinerja Dinas
Kebudayaan dan Pariwisata Provinsi Bali. Denpasar : Dispar

Dinas Kebudayaan dan Pariwisata Provinsi Nusa Tenggara Barat. (2017). Laporan Kinerja Dinas Kebudayaan dan Pariwisata Provinsi Nusa Tenggara Barat. Mataram: Dispar

Handayaningrat, Soewarno. 2003. Pengantar Studi ilmu Administrasi dan Manajemen. Jakarta : Gunung Agung

Handoko, T. Hani. 2012. Manajemen Personalia dan Sumber Daya Manusia. Yogyakarta : BPFE

Harahap, Sofyan Syarif. 2004. Analisis Kritis Atas Laporan Keuangan. Jakarta : PT Raja Grafindo Persada

Jaelani, Abdul Kadir. 2018. Pengembangan Destinasi Pariwisata Halal Pada Era Otonomi Luas di Provinsi Nusa Tenggara Barat. Jurnal Pariwisata Volume 5 Nomor 1 Tahun 2018

Komarudin. 2001. Ensiklopedia Manajemen, Edisi IX. Jakarta : Bumi Aksara

Maleong, Lexy J. 2017. Metode Penelitian Kualitatif. Bandung : PT. RemajaRosdakarya.

Maswarti, Sri. 2019. Penerapan Halal Tourism Dalam Upaya Meningkatkan Jumlah Wisatawan Di Kabupaten Lombok Timur. Jurnal Universitas Muhammadiyah Yogyakarta

Sugiyono. 2013. Metode Penelitian Pendidikan Pendekatan Kuantitatif, Kualitatif, dan R\&D. Bandung: Alfabeta

Sudrajat, M Subana. 2005. Dasar-dasar Penelitian Ilmiah. Bandung: Pustaka setia

Terry, George R. 2006. Prinsip-prinsip Manajemen. Jakarta: Bumi Aksara

Tim Kementrian Pariwisata. 2018. Desain Strategi Rencana Aksi Pariwisata Halal Nusa Tenggara Barat. Mataram : Kementrian Pariwisata Indonesia

Zaini. 2019. Pengembangan Pariwisata Halal Berbasis Masyarakat Untuk Meningkatkan Kesejahteraan (Studi Kasus di Desa Sembalun Lawang Lombok Timur). Tesis Program Magister Ekonomi Syariah UIN Malik Ibrahim Malang 
Peraturan Perundang-undangan

Peraturan Daerah Provinsi NTB No. 2

Tahun 2016 Tentang Pariwisata Halal

\section{Internet}

Anonim. 2019. Desa Wisata Tete Batu Lombok.

https://gotripina.com/blog/Desa-wisatatetebatu-lombok. Diakses pada tanggal 22 Juni 2020 pada pukul 13.00 WITA

Khafid, Soepriyanto. 2019. Tete Batu Tempat Berlibur Sejak Zaman Dahulu.

https://lomboknews.id/tete-batu-tempatberlibur-sejak-zaman-dulu/. Diakses pada tanggal 22 Juni 2020 pada pukul 13.30 WITA 